\title{
Electrophilic Cyanate As a Recognition Motif for Reactive Sulfur Species: Selective Fluorescence Detection of $\mathrm{H}_{2} \mathrm{~S}$
}

\author{
Erman Karakuş, Muhammed Üçüncü, and Mustafa Emrullahoğlu* \\ Department of Chemistry, Faculty of Science, İzmir Institute of Technology, Urla, 35430, İzmir, Turkey \\ Supporting Information
}

ABSTRACT: An ESIPT-based fluorescent dye, 3-hydroxyflavone, is chemically masked with an electrophilic cyanate motif in order to construct a fluorescent probe for cellular sulfur species. This novel probe structure, displays an extremely fast, highly sensitive and selective "turn-on" type fluorescent response toward $\mathrm{H}_{2} \mathrm{~S}$. We have also documented its utility for imaging of $\mathrm{H}_{2} \mathrm{~S}$ in the living cells.

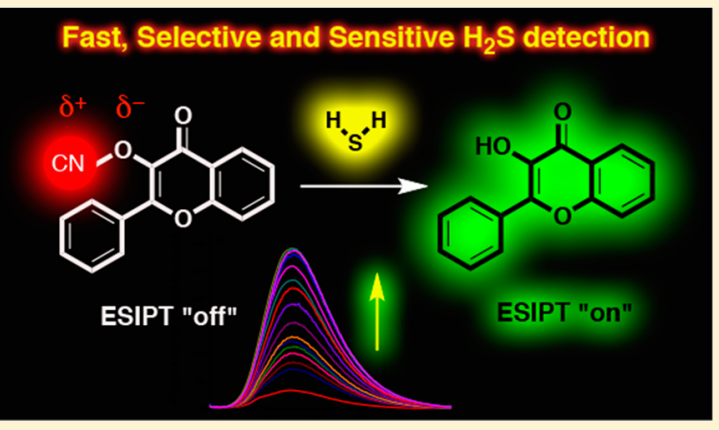

$\mathrm{H}$ ydrogen sulfide $\left(\mathrm{H}_{2} \mathrm{~S}\right)$, the smallest member among cellular sulfur species, plays critical roles in the functioning of living organisms. The compound is produced in biological systems from various sulfur-containing biomolecules and through a range of particular enzymatic pathways. ${ }^{1}$ Similar to nitric oxide (NO) and hydrogen peroxide $\left(\mathrm{H}_{2} \mathrm{O}_{2}\right)$, $\mathrm{H}_{2} \mathrm{~S}$ serves as an important gaseous signaling molecule in the nervous, inflammatory, and cardiovascular systems. ${ }^{2-5}$ Cellular $\mathrm{H}_{2} \mathrm{~S}$ is furthermore involved in an array of physiological events, including the preservation of blood flow and pressure, ${ }^{6-8}$ regulation of cell growth and death, ${ }^{9}$ reduction of ischemia reperfusion injury, ${ }^{10-12}$ regulation of inflammation, ${ }^{13}$ suppression of oxidative stress ${ }^{14,15}$ and antioxidant effects caused by reactions with free radicals. ${ }^{16-18}$ At the same time, an abnormal level of $\mathrm{H}_{2} \mathrm{~S}$ is attributable to a range of diseases such as chronic kidney disease, ${ }^{19}$ liver cirrhosis, ${ }^{20}$ and Down's syndrome. ${ }^{21,22}$

The assessment of $\mathrm{H}_{2} \mathrm{~S}$ levels in the cellular milieu is clearly vital to investigations of cell function and the early diagnosis of some diseases. Understanding the diverse contributions of $\mathrm{H}_{2} \mathrm{~S}$ to physiology and pathology therefore first requires the development of efficient methods of visualizing $\mathrm{H}_{2} \mathrm{~S}$ production and distribution in living systems. In related research, sustained attention has been paid to the development of molecular tools for probing cellular sulfur species. ${ }^{23-30}$ Among known analytical tools; fluorescence-based assays are particularly attractive, for they allow the real-time visualization of target species in cellular milieus. During the last several decades, numerous types of fluorescent $\mathrm{H}_{2} \mathrm{~S}$ probes have appeared in scientific literature on the topic, most of them involving the use of specific chemical reactions to exploit the reactive and reductive nature of $\mathrm{H}_{2} \mathrm{~S}$. ${ }^{31-41}$

In general, the construction of any reaction-based $\mathrm{H}_{2} \mathrm{~S}$ probe relies on modifying a fluorescent reporter with a reactive masking moiety, which splits away by interacting with $\mathrm{H}_{2} \mathrm{~S}$. To attain high selectivity over other relevant sulfur species, these masking moieties are necessarily highly specific to $\mathrm{H}_{2} \mathrm{~S}$ (Figure 1). ${ }^{42-48}$

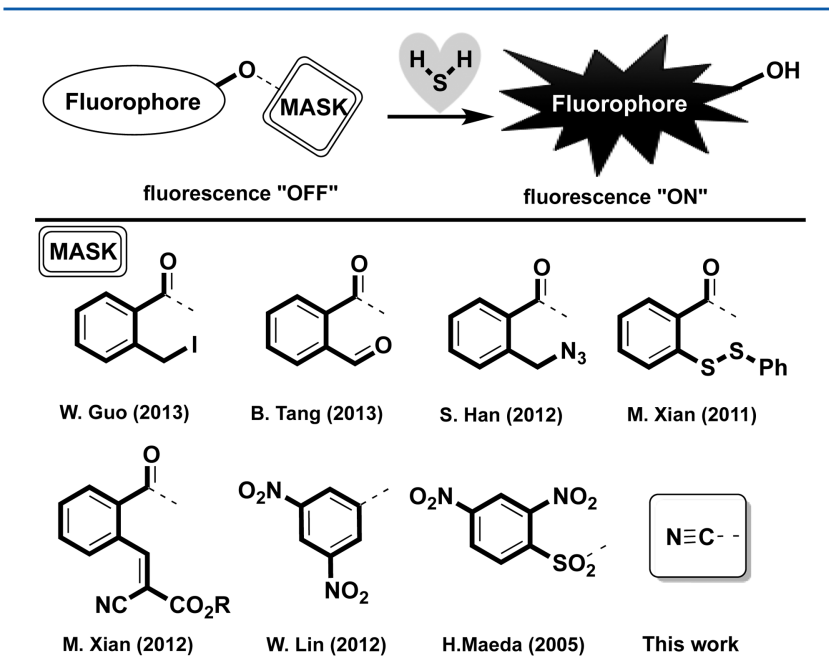

Figure 1. Selected sulfur-sensitive masking groups utilized in fluorescent probe design.

There are several important issues that have to be taken into account when designing a $\mathrm{H}_{2} \mathrm{~S}$ recognition system. At the heart of the matter lies the discrimination of $\mathrm{H}_{2} \mathrm{~S}$ over other biological sulfur species such as cysteine and glutathione. Low sensitivity and prolonged response times are other significant stumbling blocks that require attention. Moreover, most masking groups used in probe structures are relatively large

Received: October 28, 2015

Accepted: December 2, 2015

Published: December 2, 2015 
organic molecules that have to be prepared individually. In fact, throughout the sensing process, these large masking groups are delivered to the sensing system as organic waste, raising a concern of toxicity. In response, new sensing molecules that use easily accessible and biologically compatible recognition units with improved sensitivity, response times and analyte specificity are needed.

To address these challenges, we have developed a quickly responsive, highly sensitive fluorescent probe for imaging cellular $\mathrm{H}_{2} \mathrm{~S}$ with excellent selectivity over other potentially competing species. For our probe design, we used an excitedstate intramolecular proton transfer (ESIPT)-based fluorescent dye, 3-hydroxyflavone as the signal reporter due to its outstanding photophysical properties, and for the first time in the literature, an electrophilic cyanate $(\mathbf{R O}-\mathbf{C N})$ as the $\mathrm{H}_{2} \mathrm{~S}$ recognition motif.

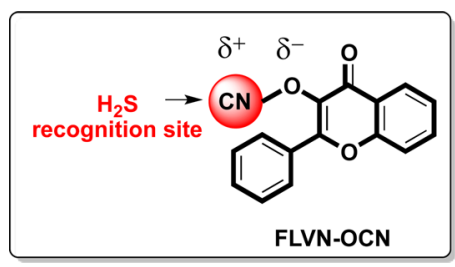

Figure 2. Molecular structure of FLVN-OCN.

\section{EXPERIMENTAL SECTION}

General Methods. All reagents were purchased from commercial suppliers (Aldrich and Merck) and used without further purification. ${ }^{1} \mathrm{H} \mathrm{NMR}$ and ${ }^{13} \mathrm{C} \mathrm{NMR}$ were measured on a Varian VNMRJ 400 nuclear magnetic resonance spectrometer. UV absorption spectra were obtained on Shimadzu UV2550 Spectrophotometer. Fluorescence emission spectra were obtained using Varian Cary Eclipse Fluorescence spectrophotometer. Cell imaging was performed with Zeiss Axio fluorescence microscope. Samples were contained in $10.0 \mathrm{~mm}$ path length quartz cuvettes $(2.0 \mathrm{~mL}$ volume $)$. Upon excitation at $415 \mathrm{~nm}$, the emission spectra were integrated over the range 435 to $700 \mathrm{~nm}$ (Both excitation and emission slit width $10 \mathrm{~nm} /$ $10 \mathrm{~nm}$ ). $\mathrm{pH}$ was recorded by HI-8014 instrument (HANNA). All measurements were conducted at least in triplicate.

Synthesis of 3-(cyanooxy)-hydroxyflavone (FLVNOCN). Compounds 1 and 3-hydroxyflavone were prepared according to literature procedures. ${ }^{49}$ A solution of cyanogen bromide $(130 \mu \mathrm{L}, 0.4 \mathrm{mmol})$ in anhydrous tetrahydrofuran (1 $\mathrm{mL}$ ) was cooled to $-10{ }^{\circ} \mathrm{C}$ (dry ice/acetone bath). Then, a solution of 3-hdroxyflavone (1) (104 mg, $0.4 \mathrm{~mol}$ ) and triethylamine $(58 \mu \mathrm{L}, 0.4 \mathrm{mmol})$ in anhydrous tetrahydrofuran $(1 \mathrm{~mL})$ was added dropwise with magnetic stirring under argon atmosphere. A white precipitate of triethylammonium bromide salt was observed. The mixture was allowed to stir for $1 \mathrm{~h}$. The solution was separated from the salt by filtration and concentrated in vacuo and purified by column chromatography (Hexane:EtOAc 4:1) to afford the compound FLVN-OCN as a white solid. (\% 80 isolated yield). ${ }^{1} \mathrm{H} \mathrm{NMR}\left(400 \mathrm{MHz}, \mathrm{CDCl}_{3}\right)$ $\delta: 8.11(\mathrm{~d}, J=8.4,1 \mathrm{H}), 8.04(\mathrm{~d}, J=6.8,1 \mathrm{H}), 7.91-7.90(\mathrm{~m}$, $1 \mathrm{H}), 7.64-7.56(\mathrm{~m}, 1 \mathrm{H}), 7.50-7.42(\mathrm{~m}, 4 \mathrm{H}), 7.34-7.28(\mathrm{~m}$, 1H). ${ }^{13} \mathrm{C}$ NMR $\left(100 \mathrm{MHz}, \mathrm{CDCl}_{3}\right) \delta: 172.0,157.5,156.5$, $155.5,154.8,134.3,134.0,131.8,128.9,128.6,125.8,125.4$,
125.0, 123.5, 118.1. Anal. cald. for $\mathrm{C}_{16} \mathrm{H}_{9} \mathrm{NO}_{3}$ : C, 73.0; $\mathrm{H}, 3.45$; N, 5.32 found; C, 72.5; H, 3.06; N, 5.03.

Cell Imaging. Human A549 lung adenocarcinoma cell lines were grown in DMEM supplemented with $10 \%$ FBS (fetal bovine serum) in an atmosphere of $5 \% \mathrm{CO}_{2}$ at $37{ }^{\circ} \mathrm{C}$. The cells were plated on $12 \mathrm{~mm}$ cover glasses in 6 well plate and allowed to grow for $24 \mathrm{~h}$. Before the experiments, the cells were washed with PBS buffer, and then cells were treated with $2 \mathrm{mM} \mathrm{N}$ methylmaleimide (NMM). After 30 min of NMM-treatment at $37^{\circ} \mathrm{C}$, cells were washed with PBS three times. Then FLVNOCN $(10 \mu \mathrm{M})$ was added and incubated for $30 \mathrm{~min}$ at $37^{\circ} \mathrm{C}$ then washed with PBS three times. After incubating with $\mathrm{Na}_{2} \mathrm{~S}$ $(50 \mu \mathrm{M})$ and $\mathrm{CTAB}(3 \mathrm{mM})$ for $30 \mathrm{~min}$ at $37^{\circ} \mathrm{C}$, cells were rinsed with PBS three times, and DAPI was added and incubated for $10 \mathrm{~min}$ at $37{ }^{\circ} \mathrm{C}$ then washed with PBS three times. The fluorescence images were acquired through fluorescence microscope.

\section{RESULT AND DISCUSSION}

A cyanate $(\mathbf{R O}-\mathbf{C N})$ can be used as a reactive nitrile readily added to sulfur species with the formation of thiocarbamates that in aqueous environments rapidly hydrolyses to its hydroxyl derivative. We anticipated that the oxygen-nitrile bond of the prefluorescent dye would undergo selective cleavage in the presence of reactive sulfur species (RSS) and thereby deliver the free hydroxyl derivative of the dye (Scheme 1), which would in turn induce a turn-on type fluorescence response.

Scheme 1. Proposed Mechanism for the Detection of $\mathrm{H}_{2} \mathrm{~S}$

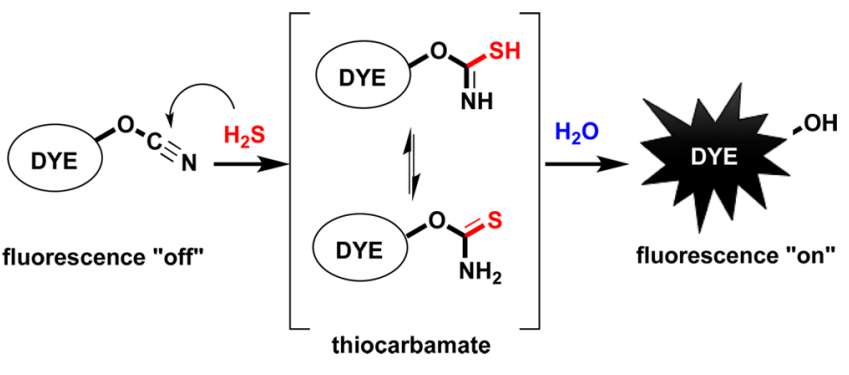

The procedure followed to prepare the probe is outlined in Scheme 2. In a single synthetic step, 3-hydroxyflavone was

Scheme 2. Synthesis of FLVN-OCN

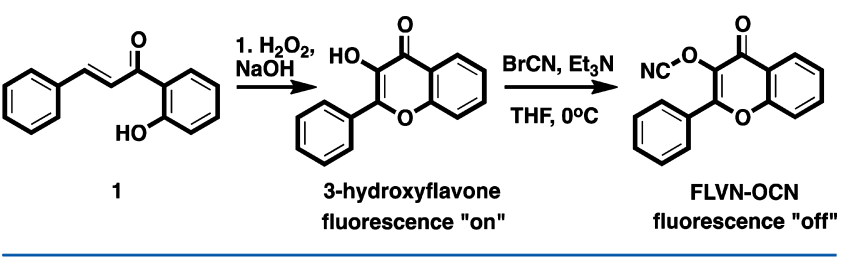

treated with commercially available cyanogen bromide in the presence of $\mathrm{Et}_{3} \mathrm{~N}$ to form the title compound, FLVN-OCN, in a good yield. FLVN-OCN remained quite stable throughout the purification process, and its identity was confirmed by NMR and elemental analysis (see Supporting Information for more details).

The spectroscopic behavior of FLVN-OCN in response to the addition of a range of reactive sulfur species together with other biologically relevant metal and ionic species was investigated by using ultraviolet (UV)-visible and fluorescence spectroscopy in an aqueous solution at $\mathrm{pH}$ 7.4. We commenced 
our investigation by screening the responses of the probe to a series of RSS, including cysteine, homocysteine, glutathione, and $\mathrm{H}_{2} \mathrm{~S}$. As typical of most ESIPT-based turn-on molecular sensors, the masked form of the dye was silent in terms of fluorescence emission. Specifically, FLVN-OCN exhibited no emission in the visible region.

However, with $\mathrm{Na}_{2} \mathrm{~S}$ or $\mathrm{NaHS}$ as the sources, the addition of $\mathrm{H}_{2} \mathrm{~S}$ to the solution of the probe immediately induced the cleavage of the masking group and concomitantly triggered the formation of the free hydroxyl group, thereby prompting the probe's "off-on" type of spectroscopic response. In the fluorescence spectrum, a new emission band appeared at 525 $\mathrm{nm}$ due to a characteristic ESIPT-modulated fluorescence response. At the same time, $\mathrm{H}_{2} \mathrm{~S}$ could easily be monitored by the naked eye due to its distinct color as well as under the UV lamp due to its changed emission of solution. To our delight, FLVN-OCN showed exceptional selectivity toward $\mathrm{H}_{2} \mathrm{~S}$, for no significant changes were monitored in the presence of other competing biothiols such as cysteine, homocysteine, and glutathione.

With the systematic addition of $\mathrm{H}_{2} \mathrm{~S}$ to FLVN-OCN, the emission band at $525 \mathrm{~nm}$ increased linearly over a wide concentration range of $\mathrm{H}_{2} \mathrm{~S}$ (Figure $3 \mathrm{~b}$ ). Meanwhile, the addition of $\mathrm{H}_{2} \mathrm{~S}$ prompted the appearance of a new absorption band at $425 \mathrm{~nm}$, with a concomitant decrease in the band at
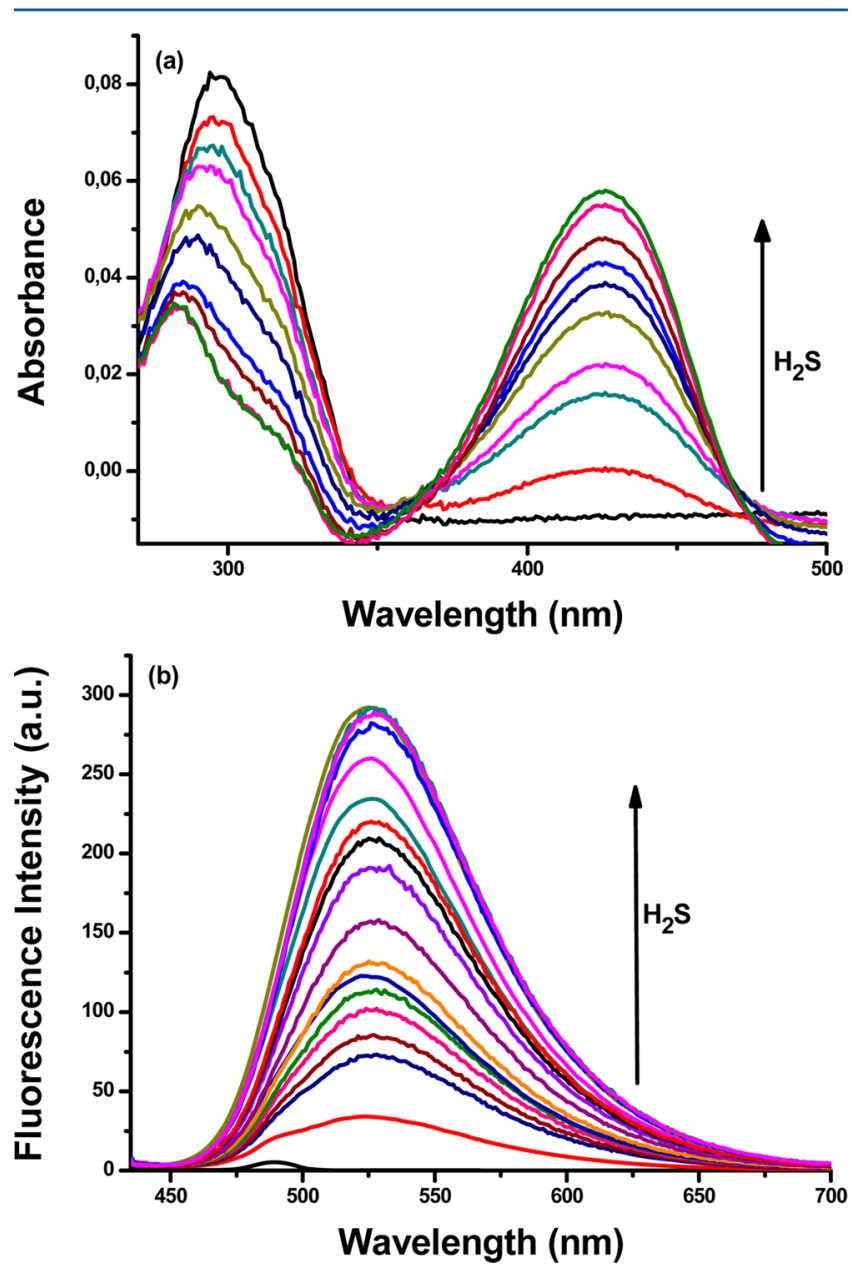

Figure 3. (a) Absorption titration curve of FLVN-OCN $(10 \mu \mathrm{M})$ and $\mathrm{H}_{2} \mathrm{~S}$ (0-10 equiv) at $\mathrm{pH}$ 7.4. (b) Emission titration curve of FLVNOCN $(10 \mu \mathrm{M})$ and $\mathrm{H}_{2} \mathrm{~S}$ (0 to 10 equiv) at $\mathrm{pH}$ 7.4.
$297 \mathrm{~nm}$. Under well-established sensing conditions ( $\mathrm{pH} 7.4$, cetrimonium bromide (CTAB) $3 \mathrm{mM}$ ), we evaluated the detection limit to be $0.25 \mu \mathrm{m}$ based on $\mathrm{S} / \mathrm{N}=3$ (Figure S9). The use of CTAB, in agreement with other reports ${ }^{35,40}$ showed a dramatic contribution to the sensitivity of the sensing system (Figure S8). Notably, under these conditions the response of FLVN-OCN to $\mathrm{H}_{2} \mathrm{~S}$ at varying concentrations was exceptionally fast $(<1 \mathrm{~min})$, and the signal intensity reached its maximum in about $5 \mathrm{~min}$ for varying equivalents of $\mathrm{H}_{2} \mathrm{~S}$, which marks one of the fastest reaction-based probes developed for $\mathrm{H}_{2} \mathrm{~S}$ (Figure $\mathrm{S} 2$ ).

In addition, we investigated the possible effects of $\mathrm{pH}$ fluctuations in the detection of $\mathrm{H}_{2} \mathrm{~S}$. Remarkably, FLVN-OCN showed exceptional stability over a wide $\mathrm{pH}$ range $(\mathrm{pH} 2-9)$ while remaining nonemissive over the same range. Even in acidic and basic environments, there were no indications of any decomposition of the probe structure. Meanwhile, the response of FLVN-OCN to the addition of $\mathrm{H}_{2} \mathrm{~S}$ also remained insensitive to changes in the $\mathrm{pH}$. We have also inspected the impact of the added analytes on changing the $\mathrm{pH}$ of the sensing media. Systematic control of the solution $\mathrm{pH}$, before and after the incubation of $\mathrm{H}_{2} \mathrm{~S}$, proved that the $\mathrm{pH}$ of sensing environment remains constant at $\mathrm{pH}$ 7.4. Consequently, FLVN-OCN operates efficiently toward $\mathrm{H}_{2} \mathrm{~S}$ over a wide $\mathrm{pH}$ range ( $\mathrm{pH} 4-9)$, especially under physiological conditions, which is of course imperative for imaging studies of living cells (Figure S7).

To further establish the selectivity of FLVN-OCN, we screened a host of other potentially competing species for their biological significance. As Figure 4 shows, we detected no changes in fluorescence emission in the presence of an excess of other reactive species such as $\mathrm{H}_{2} \mathrm{O}_{2}$ and $\mathrm{HOCl}$ and natural amino acids lacking sulfur functionality, including alanine, arginine, histidine, lysine, methionine, and proline. Moreover, other counterions such as $\mathrm{F}^{-}, \mathrm{Cl}^{-}, \mathrm{CN}^{-}, \mathrm{SCN}^{-}, \mathrm{S}_{2} \mathrm{O}_{3}{ }^{2-}, \mathrm{S}_{2} \mathrm{O}_{5}{ }^{2-}$, $\mathrm{PO}_{4}{ }^{2-}$, and $\mathrm{SO}_{4}{ }^{2-}$, as well as some metal species, including $\mathrm{Pd}^{2+}, \mathrm{Hg}^{2+}, \mathrm{Cu}^{+}, \mathrm{Ag}^{+}, \mathrm{Zn}^{2+}$, and $\mathrm{Fe}^{3+}$ induced no distinct spectral changes. All of these findings indicate the exceptional selectivity of FLVN-OCN to $\mathrm{H}_{2} \mathrm{~S}$.

We also examined the possible interference of other species in the selectivity of FLVN-OCN by treating the probe with $\mathrm{H}_{2} \mathrm{~S}$ (5 equiv) in the presence of excess biologically relevant analytes (50 equiv). Nevertheless, FLVN-OCN maintained its selectivity toward $\mathrm{H}_{2} \mathrm{~S}$ without any perturbation in the fluorescence signal, even in the presence of a high concentration of other competing analytes. These results clearly suggest that FLVN-OCN can accurately detect $\mathrm{H}_{2} \mathrm{~S}$ in the mixtures of other related species (Figure S6).

We propose that the mechanism of detection is analogous to what has been reported in the literature. ${ }^{50}$ Accordingly, $\mathrm{H}_{2} \mathrm{~S}$ readily adds to the electrophilic carbon atom of aryl cyanate to yield a thiocarbamate derivative that rapidly hydrolyses in the presence of water to its highly emissive hydroxyaryl derivative (Scheme 1). We consider that the rate of addition determines analyte selectivity. As such, with stronger nucleophiles (e.g., $\mathrm{H}_{2} \mathrm{~S}, \mathrm{p} K_{\mathrm{a}}=7.0$ ), addition to the carbon triple bond occurs at a far higher rate than with weaker nucleophiles (e.g., cysteine and glutathione, $\mathrm{p} K_{\mathrm{a}}=8.4$ ), which clearly accounts for the probe's exceptional selectivity toward $\mathrm{H}_{2} \mathrm{~S}$.

The promising results of sensing $\mathrm{H}_{2} \mathrm{~S}$ in the solution encouraged us to further assess the feasibility of the probe to detect $\mathrm{H}_{2} \mathrm{~S}$ in living cells. To this end, human lung adenocarcinoma cells (A-549) were first treated with $2 \mathrm{mM}$ 

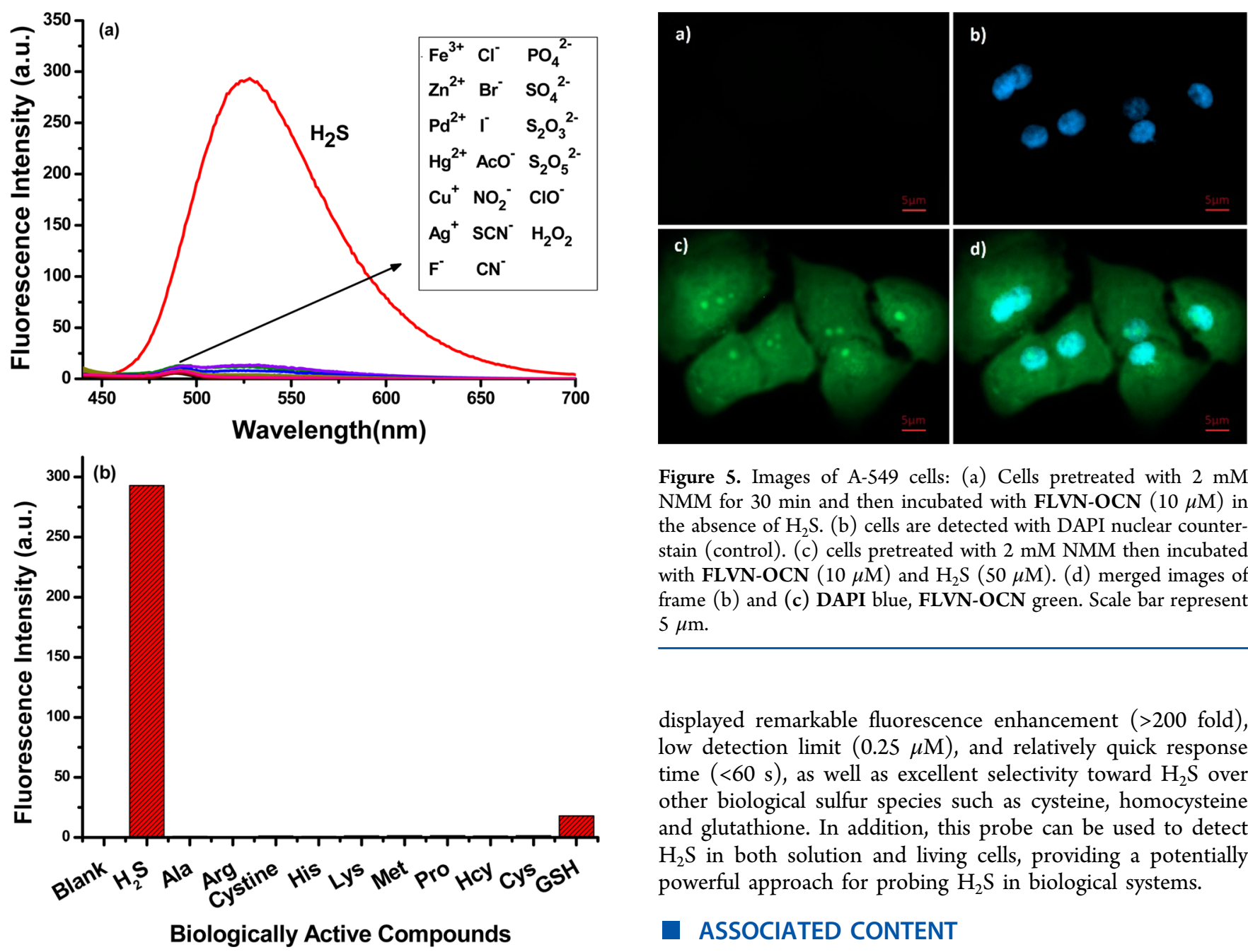

Figure 4. (a) Fluorescence intensities of FLVN-OCN $(10 \mu \mathrm{M})$ in an aqueous solution at $\mathrm{pH} 7.4$, emission at $525 \mathrm{~nm}\left(\lambda_{\mathrm{ex}}: 415 \mathrm{~nm}\right)$ : in the presence of $\mathrm{H}_{2} \mathrm{~S}$ (5 equiv) and other ions/cations (50 equiv). (b) in the presence of $\mathrm{H}_{2} \mathrm{~S}$ (5 equiv) and biologically active compounds (50 equiv).

$N$-methylmaleimide (NMM), a sulfur-trapping agent, to eliminate physiological sulfur species from the cell. The cells were then incubated with FLVN-OCN $(10 \mu \mathrm{M})$ for $30 \mathrm{~min}$, to which were added $\mathrm{Na}_{2} \mathrm{~S}(50 \mu \mathrm{M})$ and $\mathrm{CTAB}(3 \mathrm{mM})$ and incubated for another $30 \mathrm{~min}$. The cells were stained with a nucleus staining dye (DAPI) for another $10 \mathrm{~min}$, and fluorescence images were taken before and after the addition of $\mathrm{Na}_{2} \mathrm{~S}(50 \mu \mathrm{M})$.

As Figure 5 shows, the human lung adenocarcinoma (A549) cells incubated with FLVN-OCN did not display any fluorescence in the absence of $\mathrm{Na}_{2} \mathrm{~S}$ species, yet began to emit strongly after incubation with $\mathrm{Na}_{2} \mathrm{~S}$. Based on the nucleus counter stain and the characteristic green fluorescence emitting from the cells, we thus conclude that the probe passes through the cell membrane and detects exogenous $\mathrm{H}_{2} \mathrm{~S}$ from within the cell. The fluorescent microscopy measurement clearly establishes that the probe can be used for imaging $\mathrm{H}_{2} \mathrm{~S}$ in living cells.

\section{CONCLUSION}

In sum, we have developed a fluorescent probe for $\mathrm{H}_{2} \mathrm{~S}$ by modifying an ESIPT-based fluorescent dye with a cyanate ( $\mathbf{O}-$ CN) unit as an $\mathrm{H}_{2} \mathrm{~S}$-specific recognition motif. The probe
Figure 5. Images of A-549 cells: (a) Cells pretreated with $2 \mathrm{mM}$ NMM for $30 \mathrm{~min}$ and then incubated with FLVN-OCN $(10 \mu \mathrm{M})$ in the absence of $\mathrm{H}_{2} \mathrm{~S}$. (b) cells are detected with DAPI nuclear counterstain (control). (c) cells pretreated with $2 \mathrm{mM}$ NMM then incubated with FLVN-OCN $(10 \mu \mathrm{M})$ and $\mathrm{H}_{2} \mathrm{~S}(50 \mu \mathrm{M})$. (d) merged images of frame (b) and (c) DAPI blue, FLVN-OCN green. Scale bar represent $5 \mu \mathrm{m}$.

displayed remarkable fluorescence enhancement ( $>200$ fold), low detection limit $(0.25 \mu \mathrm{M})$, and relatively quick response time $(<60 \mathrm{~s})$, as well as excellent selectivity toward $\mathrm{H}_{2} \mathrm{~S}$ over other biological sulfur species such as cysteine, homocysteine and glutathione. In addition, this probe can be used to detect $\mathrm{H}_{2} \mathrm{~S}$ in both solution and living cells, providing a potentially powerful approach for probing $\mathrm{H}_{2} \mathrm{~S}$ in biological systems.

\section{ASSOCIATED CONTENT}

S Supporting Information

The Supporting Information is available free of charge on the ACS Publications website at DOI: 10.1021/acs.analchem.5b04163.

Characterization of FLVN-OCN and all data for UV-vis and fluorescence measurements (PDF)

\section{AUTHOR INFORMATION}

\section{Corresponding Author}

*E-mail: mustafaemrullahoglu@iyte.edu.tr.

Notes

The authors declare no competing financial interests.

\section{ACKNOWLEDGMENTS}

We gratefully acknowledge IZTECH (İzmir Institute of Technology) for financial support and İzmir Institute of Technology, Biotechnology and Bioengineering Research and Application Centre for fluorescence imaging facilities.

\section{REFERENCES}

(1) Kimura, H. Antioxid. Redox Signaling 2014, 20, 783-793.

(2) Li, L.; Rose, P.; Moore, P. K. Annu. Rev. Pharmacol. Toxicol. 2011, 51, 169-187.

(3) Szabó, C. Nat. Rev. Drug Discovery 2007, 6, 917-935.

(4) Lo Faro, M. L.; Fox, B.; Whatmore, J. L.; Winyard, P. G.; Whiteman, M. Nitric Oxide 2014, 41, 38-47.

(5) Kolluru, G. K.; Shen, X.; Kevil, C. G. Redox Biol. 2013, 1, 313318. 
(6) Köhn, C.; Dubrovska, G.; Huang, Y.; Gollasch, M. Int. J. Biomed. Sci. 2012, 8, 81-86.

(7) Jackson-Weaver, O.; Osmond, J. M.; Riddle, M.; Naik, J. S.; Gonzalez Bosc, L. V.; Walker, B. R.; Kanagy, N. L. Am. J. Physiol. Heart Circ. Physiol. 2013, 304, 1446-1454.

(8) Ariyaratnam, P.; Loubani, M.; Morice, A. H. Microvasc. Res. 2013, 90, $135-137$.

(9) Yang, G.; Wu, L.; Wang, R. FASEB J. 2006, 20, 553-555.

(10) Predmore, B. L.; Lefer, D. J.; Gojon, G. Antioxid. Redox Signaling

2012, 17, 119-140.

(11) King, A. L.; Lefer, D. J. Exp. Physiol. 2011, 96, 840-846.

(12) Calvert, J. W.; Coetzee, W.; Lefer, D. J. Antioxid. Redox Signaling 2010, 12, 1203-1217.

(13) Zanardo, R. C. O.; Brancaleone, V.; Distrutti, E.; Fiorucci, S.; Cirino, G.; Wallace, J. L. FASEB J. 2006, 20, 2118-2120.

(14) Kimura, Y.; Goto, Y.-I.; Kimura, H. Antioxid. Redox Signaling 2010, 12, 1-13.

(15) Kimura, Y. FASEB J. 2004, 1165-1167.

(16) Filipovic, M. R.; Miljkovic, J.; Allgäuer, A.; Chaurio, R.; Shubina, T.; Herrmann, M.; Ivanovic-Burmazovic, I. Biochem. J. 2012, 441, 609-621.

(17) Jones, C. M.; Lawrence, A.; Wardman, P.; Burkitt, M. J. Free Radical Biol. Med. 2002, 32, 982-990.

(18) Carballal, S.; Trujillo, M.; Cuevasanta, E.; Bartesaghi, S.; Möller, M. N.; Folkes, L. K.; García-Bereguiaín, M.; Gutiérrez-Merino, C.; Wardman, P.; Denicola, A. Free Radical Biol. Med. 2011, 50, 196-205.

(19) Perna, A. F.; Ingrosso, D. Nephrol., Dial., Transplant. 2012, 27, 486-493.

(20) Fiorucci, S.; Antonelli, E.; Mencarelli, A.; Orlandi, S.; Renga, B.; Rizzo, G.; Distrutti, E.; Shah, V.; Morelli, A. Hepatology 2005, 42, 539-548.

(21) Han, Y.; Qin, J.; Chang, X.; Yang, Z.; Du, J. Cell. Mol. Neurobiol. 2006, 26, 101-107.

(22) Kamoun, P.; Belardinelli, M.-C.; Chabli, A.; Lallouchi, K.; Chadefaux-Vekemans, B. Am. J. Med. Genet. 2003, 116, 310-311.

(23) Zhao, Y.; Biggs, T. D.; Xian, M. Chem. Commun. 2014, 50, $11788-11805$.

(24) Lin, V. S.; Chen, W.; Xian, M.; Chang, C. J. Chem. Soc. Rev. 2015, 44, 4596-4618.

(25) Li, J.; Yin, C.; Huo, F. RSC Adv. 2015, 5, 2191-2206.

(26) Shimamoto, K.; Hanaoka, K. Nitric Oxide 2015, 46, 72-79.

(27) Chen, X.; Zhou, Y.; Peng, X.; Yoon, J. Chem. Soc. Rev. 2010, 39, 2120-2135.

(28) Zeng, L.; Chen, S.; Xia, T.; Hu, W.; Li, C.; Liu, Z. Anal. Chem. 2015, 87, 3004-3010.

(29) Singha, S.; Kim, D.; Moon, H.; Wang, T.; Kim, K. H.; Shin, Y. H.; Jung, J.; Seo, E.; Lee, S.-J.; Ahn, K. H. Anal. Chem. 2015, 87, $1188-1195$.

(30) Peng, B.; Zhang, C.; Marutani, E.; Pacheco, A.; Chen, W.; Ichinose, F.; Xian, M. Org. Lett. 2015, 17, 1541-1544.

(31) Gupta, N.; Reja, S. I.; Bhalla, V.; Gupta, M.; Kaur, G.; Kumar, M. Chem. Commun. 2015, 51, 10875-10878.

(32) Xuan, W.; Pan, R.; Cao, Y.; Liu, K.; Wang, W. Chem. Commun. 2012, 48, 10669-10671.

(33) Zhang, H.; Zhang, C.; Liu, R.; Yi, L.; Sun, H. Chem. Commun. 2015, 51, 2029-2032.

(34) Zhang, J.; Guo, W. Chem. Commun. 2014, 50, 4214-4217.

(35) Liu, Y.; Feng, G. Org. Biomol. Chem. 2014, 12, 438-445.

(36) Huang, Z.; Ding, S.; Yu, D.; Huang, F.; Feng, G. Chem. Commun. 2014, 50, 9185-9187.

(37) Sasakura, K.; Hanaoka, K.; Shibuya, N.; Mikami, Y.; Kimura, Y.; Komatsu, T.; Ueno, T.; Terai, T.; Kimura, H.; Nagano, T. J. Am. Chem. Soc. 2011, 133, 18003-18005.

(38) Peng, B.; Chen, W.; Liu, C.; Rosser, A.; Pacheco, E. W.; Zhao, Y.; Aguilar, H. C.; Xian, M. Chem. - Eur. J. 2014, 20, 1010-1016.

(39) Zhao, C.; Zhang, X.; Li, K.; Zhu, S.; Guo, Z.; Zhang, L.; Wang, F.; Fei, Q.; Luo, S.; Shi, P. J. Am. Chem. Soc. 2015, 137, 8490-8498. (40) Tian, H.; Qian, J.; Bai, H.; Sun, Q.; Zhang, L.; Zhang, W. Anal. Chim. Acta 2013, 768, 136-142.
(41) Hammers, M. D.; Taormina, M. J.; Cerda, M. M.; Montoya, L. A.; Seidenkranz, D. T.; Parthasarathy, R.; Pluth, M. D. J. Am. Chem. Soc. 2015, 137, 10216-10223.

(42) Zhang, J.; Sun, Y.-Q.; Liu, J.; Shi, Y.; Guo, W. Chem. Commun. 2013, 49, 11305-11307.

(43) Wang, X.; Sun, J.; Zhang, W.; Ma, X.; Lv, J.; Tang, B. Chem. Sci. 2013, 4, 2551-2556.

(44) Wu, Z.; Li, Z.; Yang, L.; Han, J.; Han, S. Chem. Commun. 2012, 48, 10120-10122.

(45) Liu, C.; Pan, J.; Li, S.; Zhao, Y.; Wu, L. Y.; Berkman, C. E.; Whorton, R.; Xian, M. Angew. Chem., Int. Ed. 2011, 50, 10327-10329.

(46) Liu, C.; Peng, B.; Li, S.; Park, C.-M.; Whorton, R.; Xian, M. Org. Lett. 2012, 14, 2184-2187.

(47) Cao, X.; Lin, W.; Zheng, K.; He, L. Chem. Commun. 2012, 48, 10529.

(48) Maeda, H.; Matsuno, H.; Ushida, M.; Katayama, K.; Saeki, K.; Itoh, N. Angew. Chem., Int. Ed. 2005, 44, 2922-2925.

(49) Liu, X.; Liu, H.; Shen, X.; Song, B.; Bhadury, P. S.; Zhu, H.; Liu, J.; Qi, X. Bioorg. Med. Chem. Lett. 2010, 20, 4163-4167.

(50) Jensen, K. A.; Due, M.; Holm, A.; Wentrup, C. Acta Chem. Scand. 1966, 20, 2091-2106. 